\title{
Bugisese Migration and Cocoa Farming Globalization in East Kolaka
}

\author{
Syamsumarlin ${ }^{1}$, Pawennari Hijjang ${ }^{2}$, Tasrifin Tahara ${ }^{3}$, Munsi Lampe ${ }^{4}$ \\ \{syamsumarlinantrop@gmail.com ${ }^{1}$, aweunhas@yahoo.com ${ }^{2}$, tasrifin.tahara@yahoo.co.id ${ }^{3}$, \\ munsilampe257@gmail.com $\left.{ }^{4}\right\}$ \\ ${ }^{1234}$ Anthropology of Hasanuddin University Makassar, Sulawesi Selatan, Indonesia
}

\begin{abstract}
This research aimed to find out how the Bugisese Migration culture is in cultivating cocoa farming as one of local powers in responding to farming globalization in East Kolaka. Bugise Migration coming from various areas in South Sulawesi Province region aiming to massapadale or earn living. Their arrival in East Kolaka of course brought rice farming culture as livelihood in their original area that was then developed into cocoa farming until today. This research was conducted in East Kolaka Regency, using ethnographic method to represent Bugisese migration and cocoa farming globalization. Techniques of collecting data used were observation and in-depth interview. The result of research showed that cocoa or chocolate farmers in East Kolaka are one of local strengths in affecting transnational power as global power. Similarly, transnational powers affect local culture or cultural locality is created through the relationship between farmers and cocoa industry in East Kolaka. Conflict between local interest and global interest leads to friction resulting in the rules that should be implemented by local powers against transnational or global power. It is because Bugisese migrants as local power have knowledge, belief, and value, in organizing cocoa production system to pursue maximization in various aspects of social-cultural life.
\end{abstract}

Keywords-Bugisese migration, farming globalization

\section{Introduction}

Cocoa plant is one of plantation plants constituting the mainstay agricultural subsector in Indonesia. It is because Indonesia has ever been the second largest cocoa producer in the world following Pantai Gading (Cote d'Ivoire) in 2002, although its position has been replaced by Ghana in 2003 until today [1]. The role of cocoa plantation subsector is actually larger because it is closely related to industrial sector becoming middle and downstream subsystems potentially improving community's added-value and income. The potentially increasing addedvaluecoming from cocoa plantation subsector deals with local manpower, food, and economic problems. Statistic Data of South East Sulawesi Province (2018) numerically shows the distribution of cocoa area width and production as follows: North Kolaka with 79475 hectare- 
wide area and 51,298 ton production, East Kolaka with 69,574 hectare-wide area and 31,813 ton production,Kolaka Regency with 29,485 hectare-wide area and 9,961 ton production.

East Kolaka Regency is one of 17 regencies in South East Sulawesi Province. East Kolaka Regency as the result of Kolaka Regency's proliferation of administrative region consists of 118 villages and 14 Kelurahans distributed in 12 sub-district. East Kolaka Regency has 128,154 populations in 2018, with 3.18.38 Km-wide area. The populations of East Kolaka regency generally are Tolaki Mekongga, Bugisese migrating from South Sulawesi and transmigrating from Java, Bali, and Lombok Islands. East Kolaka's populations before the entrance of migrants were Tolaki Mekongga with dry field farming cultivating dry field rice, sweet potatoes, and horticultural plant being their livelihood.

The coming of Bugisese migrants from South Sulawesi with knowledge on rice farming and cocoa planting responded very well to the wide location for developing cocoa plant cultivation. Information acquired from one of Bugisese community leaders in East Kolaka showed that cocoa farmers came to East Kolaka following Bugiseses' success in developing cocoa plantation in North Kolaka. Meanwhile, there has been an expansion of cocoa planting land in South East Sulawesi since 80s, so that massive migration wave occurred from South Sulawesi to some areas in South East Sulawesi to open new cocoa plant land, including in East Kolaka.

Local knowledge of Bugiseses coming to East Kolaka with massappa dalle' conceptis a view assuming that earning living is an obligation to fulfill in order to be a successful one anywhere. It can be seen from parents' tenet to their children "Resopa temmangingi, matinulu, namalomo naletei pammase Dewata sewwa-E". Therefore, Bugisese farmer migrants cooperate with other ethnics and build work with outsider groups. Bugisese farmers can accept new knowledgeand technology easily and apply it to the farming they are preoccupied with. They experiment bravely by trying new methods to maximizing production [2].

Globalization, according to Featherstone [3], has made the world a single place through many tracks: a nation's empire hegemony or power block, or trading corporate winning, universal proletariat, a kind of religion, or world federalist movement. All of these are history that can potentially result in some mixed and integrated culture and differentiation. All of these, and phase during globalization process, need global culture production [4].

Tsing [5] stated that global connection ethnography or term "global" is not a claim to explain anything all at once in the world. However, it introduces the way of thinking of the history of social projects, including "business" and "local empowerment'. Firstly, such projects grow fractionally and are interconnected. Secondly, cultural diversity cannot be removed from this interconnection; it is this that results in them and their entire typicality. Globalization concerns not only economic issue but also cultural issue. Globalization and modernization should be viewed not only temporally as massive social transformation but also spatially and relationally. The spatial zones in this world, according to her, have become modern in many ways, thereby requiring us to speak of global modernity in varying context.

Meanwhile, Bonnie [6] stated that farming issue arises due to endless contravention and contradiction in post-colonialism structure in the communities in developing country. Such condition has resulted in farming globalization, a new situation approving a multilateral agreement regime in agricultural sector in the framework of WTO that should be complied by its member states.

Cocoa production decreased in nearly all production centers in both Indonesia and abroad in 2011. Many farmers converted their land from cocoa plant to other plants such as palm oil, clove, and even some farmers no longer utilize their cocoa plant land. Such condition led cocoa or transnational industry coming from many countries looked for partnership with cocoa partner including in Indonesia [7]. The limited basic material of cocoa industry also occurred in 
Indonesia so that some cocoa industrial companies went down to rural areas to build farmers, as explained by Chairperson of Indonesian Cocoa Council that industrial competition is getting tighter for obtaining cocoa basic material in Indonesia.

Considering such condition, the problem of cocoa farming in East Kolaka Regency is also affected by the entrance of global or transnational industrial applying science-based farming. However, the local community (Bugisese migrants)' knowledge established since they still worked on rice farm until they became cocoa farmers still affects their cocoa farming method. Therefore, a conflict arises between farmers' local knowledge and scientific knowledge of global industry.

\section{Method}

This study was an ethnographic research, the one attempting to provide qualitative data to describe the actual condition of facts in the field systematically, factually, and accurately [8]. For that reason, informants were selected using purposive sampling considering that informants should be the one knowledgeable and willing to give information related to the cocoa farming globalization issue in East Kolaka. Data was analyzed descriptively and qualitatively by representing the result of research descriptively to answer the problem studied.

\section{Result And Discussion}

Bugisese migration in many areas is common, because a characteristic of Bugisese is passompe [2]. Migration or Sompe' conducted by Bugisese people has developed and change, particularly related to the factors of sompe'. These changes result in new relationship not only reflecting elite relation, but also touching the grass-root (lower-class) society. Wandering Bugiseses not only reveals elite role in many areas but also involves ordinary people. It can be seen from their diverse social, political, and economic activities in many regions in Indonesia, including in East Kolaka Regency. The presence of migrant or passompe'in East Kolaka has passed through some stages since Colonial reign through post-independence Indonesian reign, through migration that is merely economic in nature today.

Bugisese farmers' success started to occur in 1995 when their chocolate plants began to bear fruit with a large volume of production. In this period, the competition between farmers for improving their production can be seen more clearly from their production businesses. It is because the farmers deliver their chocolate production to each other for one harvesting season, and they use management technique to improve their chocolate fruit production weekly, monthly, and yearly. This condition occurs in the farmers of East Kolaka, where the farmers respond to the environment to create and develop farming model or method corresponding to the identity developing locally. This locality is known widely as local wisdom by many social scientists and agriculturalists.

The farmers' new knowledge is constructed to respond to the nature by means of creating farming method and strategies to improve production, e.g. fertilizing according to farmers' size rather than the size or dose recommended by fertilizer or pesticide industry. This new knowledge develops well becausefarmers use the knowledge on chocolate industrial globalization based on scientific knowledge. Such the knowledge is then constructed locally, therebyresulting in more modern culture without considering the balanced ecosystem. 
Therefore, the farmers in East Kolaka generally see chocolate production as the objective to be achieved in order to be patron among fellow chocolate farmers coming from South Sulawesi or Bugisese migrants in East Kolaka.

Chocolate or cocoa has been new identity to Bugisese migrants' life in East Kolaka. Chocolate is their primary economic source (income) to chocolate farmers' life and livelihood in their diverse social-cultural activities in positioning the identity of Bugisese migrants as one of community groups in East Kolaka. Chocolate farmers in East Kolaka entered into peak production season in 1998, so that they viewed chocolate as their economic power. Therefore, they viewed that education or schooling was not too important at that time, and the most important thing was that people should have sikoolaah (chocolate) to be the prominent one among farmers.

Originally, cocoa plant in Dangia of East Kolaka was not fertilized because of its very fertile soil; however the incentive to multiply their harvest product given by Agricultural Extension Officer (PPL) led the farmers to using fertilizer. No certain data shows when the PPL did came into Dangia area, but according to Mr. Alim Bahri as the informant, he had used chemical fertilizer to improve his harvest productivity due to PPL's recommendation. Chemical fertilizer has been used by nearly all cocoa farmers in Dangia. Some informants' admitted that having used chemical fertilized, their harvest productivity increased by $30 \%$. The abundant harvest productivity made the farmers more prosperous and having much money, so that their domestic consumption increased drastically. The increase of household consumption was characterized with the community's increased expectation and interest in increasing production supportability by eliciting their family from their origin area in South Sulawesi and building partnership with cocoa industry. It can also be seen from the consumption pattern of household appliances. Nearly all people have had television using parabolic antenna, electric water pump, motorcycle, and even some others with tens-hectare land have had a car parked in their garage. The question, then, is "whether or not there has been PLN (State-Owned ElectricityCompany) electricity. The answer is of course no there has been not, but the people purchased electricity generator to operate their electronic appliances at that time.

In this period, some adagiums or proverbs developed within society: "appessanni degaga sikolana, kuangkamua siko'llana (schooling is not important as long as there is cocoa plantation)". It is because of abundant harvest output, so that cocoa became very valuable to the people in Dangia. To some people, giving their children high education was not a priority, because children, particularly sons, were the production tool in cocoa plantation. Enrolling the children, particularly sons, in high education would reduce production tool because their children would leave their village. Thus, they will marry off their pubertal sons immediately with the girls coming from the same village or the different villages adjacent or those having kinship. Early marriage occurred very prevalently at that time, because money (as dowry or uangpanaik) was not the meaningful problem due to their more abundant harvest productivity. The pubertal girl would be married off immediately when a boy has proposed her.

Marriage, to Bugiseses, is not merely religion's advice, but it also has social political dimension. Bugiseses perform social class mobility through marriage. If they can fulfill "uangpanaik (dowry), a boy can choose the girl he wants. Marriage, to Bugiseses, particularly female Bugiseses, meant more mating, although some of them started it with dating. In that period, a glamour wedding would be found widely after cocoa harvest peak season, before fasting months. Cocoa (chocolate) farmer community in Dangia and East Kolaka hold wedding party commonly after chocolate great harvest time. 


\section{Conclusion}

Cocoa farmers in Kolaka have developed farming system by integrating local knowledge and global knowledge, so that they can maximize production by using excessive fertilizer and pesticide. On the other hand, this model can improve productivity maximally for some years, but instead it will exert adverse effect due to environmental or ecological damage if it is done continuously. This condition results in "antara beranta" farming according to Laksono [9], or disorganized farming according to Tsing [5], Considering how globalization works in Dangia community in East Kolaka, a strategy issue is revealed that is more relevant to use than resistance issue. People do not decline globalization, but do not accept it haphazardly as hegemony. They modify and utilize it corresponding to the interests favorable to them. Locality is not defined as their subjection to globalization, but as the part of complex global connection.

\section{References}

[1] Novalia, “10 Negara Penghasil Kakao Terbesar Di Dunia,” Seputar Forex, 2019. .

[2] C. Pelras, Manusia Bugis. Jakarta: Forum Jakarta Paris, 2006.

[3] M. Featherstone, Global Culture: Nationalism, globalization and modernity. London: SAGE Publications, 1997.

[4] D. Mulyanto, Genealogi Kapitalisme, Antropologi dan Ekonomi Politik Pranata Eksploitasi Kapitalistik. Yogyakarta: Resist Book, 2012.

[5] A. L. Tsing, Friction: An Ethnography Of Global Connection. Princeton: Princeton University Press, 2005.

[6] B. Setiawan, Globalisasi Pertanian: Ancaman Atas Kedaulatan Bangsa dan Kesejahteraan Petani. Jakarta: Institute for Global Justice, 2003.

[7] M. L. Tania, The Will to Improve: Perencanaan, Kekuasaan, dan Pembangunan di Indonesia. Penerjemah: Hery Santoso dan Pujo Semedi. Yogyakarta: Marjin Kiri, 2012.

[8] J. Spradley, Metode Etnografi. Yogyakarta: Tiara Wacana, 1997.

[9] P. M. Laksono, "Tanpa Tanah-Budaya Nir-Papan Antropologi Anta Berantah," in Berebut Tanah Beberapa Kajian Kampus Berprespektif Kamus Dan Kampung, Yogyakarta: Insist Press, 2000. 